\section{Secondary Structure within PCR Target Sequences May Facilitate Heteroduplex Production}

\section{E. Separovic ${ }^{1}$ and S.A. Nadin-Davis}

Pathobiology section, ADRI Nepean, Agriculture Canada, Nepean, Ontario, Canada $\mathrm{K} 2 \mathrm{H} 8 \mathrm{P} 9$

\footnotetext{
1 Present address: University of Ottawa Faculty of Medicine, IKEDA Genosphere Project, Ottawa, Ontario, Canada K1H 8N5.
}

PCR amplification is currently being used extensively to amplify selected regions of viral genomes in order to provide material for precise sequence determination. The human immunodeficiency viruses (HIVs) responsible for AIDS have been especially targeted by this approach because of their quasispecies nature and relatively high capacity for mutation. ${ }^{(1,2)}$ It appears that a full understanding of the complex pathogenicity of HIV and related animal lentiviruses will require correlation of the replicative and cytopathic properties of individual viral variants appearing in vivo with specific sequence motifs. ${ }^{(3,4)}$

The simian immunodeficiency viruses (SIVs) are primate lentiviruses being used extensively as HIV models in pathogenicity studies and for the investigation of vaccination and therapeutic strategies. As in HIV infections of humans, infected animals harbor multiple genotypes. $^{(5)}$ Differences between genomes are largely the result of nucleotide substitutions, although small insertions and deletions have also been reported. ${ }^{(6,7)}$ The SIV $_{\text {pbj } 14}$ strain is especially useful for certain in vivo studies because of its high pathogenicity and rapid clinical course; in pigtailed and cynomolgus macaques this strain causes fatal disease within 8-14 days of infection. ${ }^{(8.9)}$ One notable feature of this strain is the presence of a 22-bp duplication within the $\mathrm{U} 3$ portion of the long terminal repeat (LTR) in a significant proportion of viral genomes in the viral stock. $^{(8,10)}$ This duplication includes a complete copy of the NF-кB transcription enhancer-binding site. Although it has been shown that this duplication is not responsible for the highly pathogenic nature of this strain, ${ }^{(11)}$ its role in pathogenicity is still of interest because the NF- $\mathrm{B}$-binding site is necessary for efficient replication of SIV in certain cell types. ${ }^{(12)}$

We have used the $\operatorname{SIV}_{\mathrm{pbj14}}$ strain to investigate methods of inactivation of lentiviruses that might be applied to blood or partially purified blood components. As part of this study (details to be published elsewhere) we developed PCRs directed to three portions [ $\mathrm{gag}, \mathrm{pol}$, and LTR sequences] of the SIV genome. The primers directed to the LTR target sequence flank the region of duplication. In this report we describe an observation made during the use of the LTR primers. In addition to the two expected
PCR products, an extra band of apparently higher molecular weight was generated in virtually stoichiometric amounts. We have shown this band to be a heteroduplex produced artifactually during the amplification process. We suspect that the potential for significant secondary structure within the duplicated sequence facilitated this phenomenon.

\section{MATERIALS AND METHODS}

\section{Viral Propagation and Animal Infection}

The $\mathrm{SIV}_{\mathrm{pbi14}}$ strain (obtained from Dr. H. McClure, Yerkes Regional Primate Center, Emory University, Atlanta, GA) was grown in human CEMX174 cells and titered as described previously. ${ }^{(9,10)}$ Cynomolgus monkeys received doses of SIV $_{\text {pbi14 }}$ corresponding to 1,10 , and 100 $\mathrm{TCID}_{50}$, and animals were sacrificed within 14 days of inoculation. In some cases, monkeys received virus recovered from previously infected animals. At intervals and at time of death, blood was removed and used to prepare peripheral blood leukocytes (PBLs) by standard buffy coat techniques. In addition, lymph node tissue was taken prior to infection and at autopsy. Virus was propagated from these samples by coculture with CEMX174 cells.

\section{Isolation of DNA and PCR}

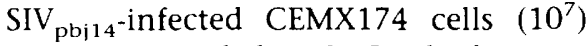
were resuspended in $0.45 \mathrm{ml}$ of extraction buffer ( $20 \mathrm{~mm}$ Tris- $\mathrm{HCl}$ at $\mathrm{pH} 8.0,50$ $\mathrm{mm} \mathrm{NaCl}, 5 \mathrm{~mm}$ EDTA, $0.5 \%$ SDS) and incubated overnight at $55^{\circ} \mathrm{C}$ with $50 \mu \mathrm{g}$ proteinase $\mathrm{K}$. After two extractions with 1 volume of phenol and one extraction with 1 volume of phenol/chloroform, the final aqueous phase was ethanol precipitated. The DNA pellet was dissolved in $200 \mu \mathrm{l}$ of $1 \times$ TE buffer.

Genomic DNA (1-2 $\mu \mathrm{g})$ was used for PCR performed in $10 \mathrm{~mm}$ Tris- $\mathrm{HCl}(\mathrm{pH}$ 8.8), $50 \mathrm{~mm} \mathrm{KCl}, 1.5 \mathrm{~mm} \mathrm{MgCl}_{2}, 0.1 \%$ Triton X-100, all four dNTPs, each at 0.1 $\mathrm{mm}$, both primers at $0.5 \mathrm{~nm}$ each, and 2 units of Taq DNA polymerase. Amplification was performed in a Perkin-Elmer Cetus DNA thermal cycler using $40 \mathrm{cy}$ cles consisting of denaturation at $94^{\circ} \mathrm{C}$ for $1 \mathrm{~min}$; annealing at $65^{\circ} \mathrm{C}$ for $1 \mathrm{~min}$; extension at $72^{\circ} \mathrm{C}$ for $2 \mathrm{~min}+5 \mathrm{sec}$ autoextension. PCR products were ob- 
served by ethidium bromide staining after electrophoresis in 4\% NuSieve-3:1 agarose. The primers used in all of these studies were LTR1, 5'-AGAAGGCTAACCGCAAGAGGCCTT-3', and LTR2, 5' -GACTGAATACAGAGCGAAATGCAG-3'; the sequences are derived from GenBank accession number M80193, and they correspond to positions $9310-9333$ and 9480-9503 of the SIV $_{\mathrm{pbj} 14}$ genome.

\section{Purification and Analysis of PCR Fragments}

Subsequent to separation by electrophoresis, DNA fragments were cut from the gel and purified using the "Mermaid kit" according to the manufacturer's (Bio 101) protocol. To determine precise sizes of these DNA products, purified or total PCR products were end-labeled with $\left[\gamma^{32} \mathrm{P}\right] A T P$ (DuPont) and polynucleotide kinase and electrophoresed through a $6 \%$ acrylamide sequencing gel. A sequencing reaction from unrelated studies corun with these samples provided precise size markers. Restriction endonuclease digestion of the DNA fragments was performed by standard methods, and products were electrophoresed as described.

\section{RESULTS AND DISCUSSION}

Amplification of the $\mathrm{SIV}_{\mathrm{pbj14}}$ LTR target sequence was expected to generate two discrete products, one of $172 \mathrm{bp}$, which contains only one copy of the NF-кB site, and one of $194 \mathrm{bp}$, which carries a second NF-kB site within the 22-bp insertion. Both products were observed after genomic DNA from cells persistently infected with this SIV strain were subjected to PCR as described. Digestion of these products with the restriction enzymes DdeI, Rsal, and StuI confirmed their identity by yielding products of the expected sizes (data not shown). Furthermore, neither reagent control reactions nor DNA from uninfected control cells gave such amplification products. The larger band was the more intense, indicating that the genomes with the duplication predominate. In addition to the two expected products, a third band of $\sim 220$ bp was observed in PCRs of DNA from $\mathrm{SIV}^{+}$cells.

The viral stock was used to infect six monkeys as described, and virus was recovered from PBLs by coculture. DNA purified from cultured cells was analyzed by PCR. For five of these monkeys there was a single amplification product: Three monkeys gave only the 172-bp product and two other monkeys gave only the 194-bp product, whereas in one monkey (M2) all three products (174, 192 , and $220 \mathrm{bp}$ ) were found.

We were initially intrigued with the possibility that the 220-bp band represented a population of $\operatorname{SIV}_{\mathrm{pbi14}}$ having an additional duplication in the LTR target sequence, especially because a molecular clone of $\mathrm{SIV}_{\mathrm{pbj}}$ has been found to contain three NF- $\mathrm{KB}$ sites. ${ }^{111}$ To further characterize this DNA fragment, it was purified from a gel and aliquots representing $1-5 \%$ of the initial product were reamplified to provide sufficient material for direct DNA sequencing. We observed, however, that after reamplification of the 220-bp fragment, PCR products of all three sizes were consis tently made in apparently stoichiometric amounts, despite the apparent purity of the original material (Fig. 1). When the two smaller products (172 and 194 bp) were gel purified and reamplified, they generated predominantly single PCR products of their respective sizes (Fig. 1). This latter observation indicated that our separation techniques were relatively clean.

The finding that we were unable to generate a single $\mathrm{PCR}$ product from the 220-bp band, taken together with the fact that this fragment was produced

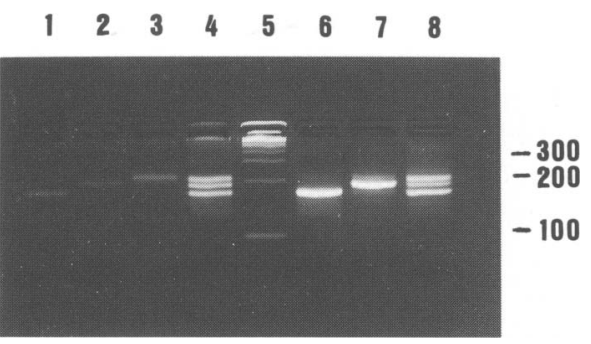

FIGURE 1 PCR amplification of the SIV $\mathrm{pbbj14}_{14}$ LTR. DNA isolated from human CEMX174 cells cocultured with PBLs from monkey M2 was amplified using primers LTR1 and LTR2 to generate three discrete products of apparent size 172,194 , and 220 bp (lane 4). Each DNA fragment was gel purified and rerun to verify purity: (Lane 1) $172 \mathrm{bp}$; (lane 2) $194 \mathrm{bp}$; (lane 3) $220 \mathrm{bp}$. Purified fragments were reamplified separately, and the resulting products, using DNA bands 172,194 , and 220 bp, respectively, as template, are shown in lanes 6-8. A 100-bp marker D.NA (Life Technologies) is shown in lane 5 .

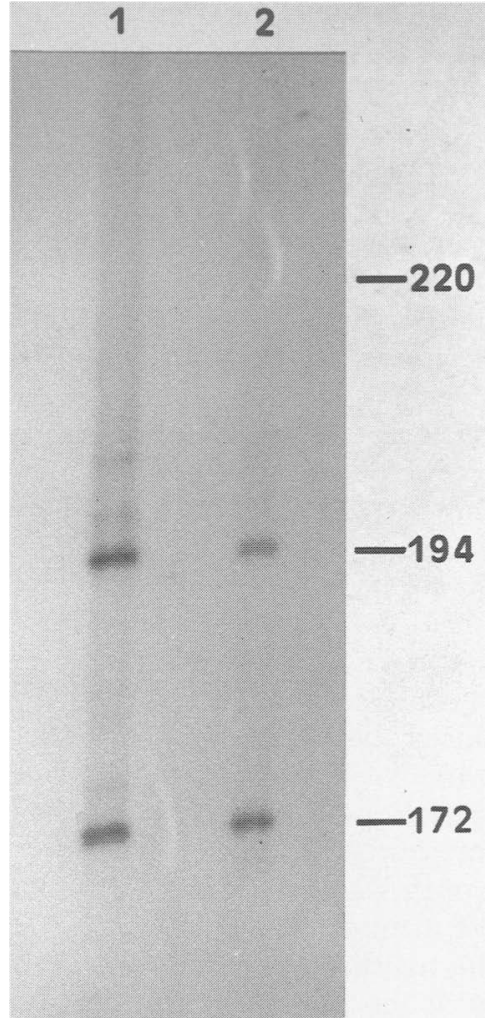

FICURE 2 Analysis of PCR products by denaturing gel electrophoresis. The products of PCR reamplification of the 220 -bp fragment (lane 1) or the three fragments of the original PCR from M2 DNA (lane 2) were radiolabeled with ${ }^{32} \mathrm{P}$, electrophoresed on a $6 \%$ acrylamide sequencing gel, and exposed to X-ray film. The resulting autoradiograph is shown, together with the estimated size of the two DNA bands, as determined by a sequencing reaction run in parallel. The position at which a 220 -base fragment would migrate is also shown.

only when both of the two smaller products were made, suggested that the larger band was an artifact. To accurately determine the sizes of all DNA strands in the PCR product, an aliquot of a PCR in which all three DNA bands had been produced was end-labeled with ${ }^{32} \mathrm{P}$ and electrophoresed on a denaturing acrylamide gel. After autoradiography, only two main bands with the expected sizes of 172 and 194 bases were observed (Fig. 2 , lane 2 ). The same pattern was seen when the gel-purified 220-bp fragment was analyzed in a similar manner (Fig. 2, lane 1). No signal was observed at the 220-base position. This showed that the 220-bp product was a hybrid molecule composed of a single strand from each of the two smaller fragments. The produc- 
tion of this hybrid was independent of primer extension because when a mixture of the 172-and 194-bp PCR products was subjected to 40 cycles of PCR in the absence of Taq DNA polymerase, the 220-bp band was produced (Fig. 3). It has been observed subsequently that with the relatively high amounts of template present in such "mock" PCRs, even a single round of thermal cycling is sufficient for hybrid generation. Because it is probable that the mock PCR situation closely resembles the later cycles of a PCR, when Taq polymerase activity is low, the possibility of minimizing heteroduplex production by reducing the number of PCR cycles was examined. However, PCR of SIV-infected monkey DNA using 25 cycles instead of 40 still produced the 220-bp product (data not shown). We have been unable to identify PCR conditions that eliminate this artifact but still permit sensitive detection of the target sequence.

We attribute the large apparent size of the hybrid PCR product (220 bp instead of the 183-bp value intermediate

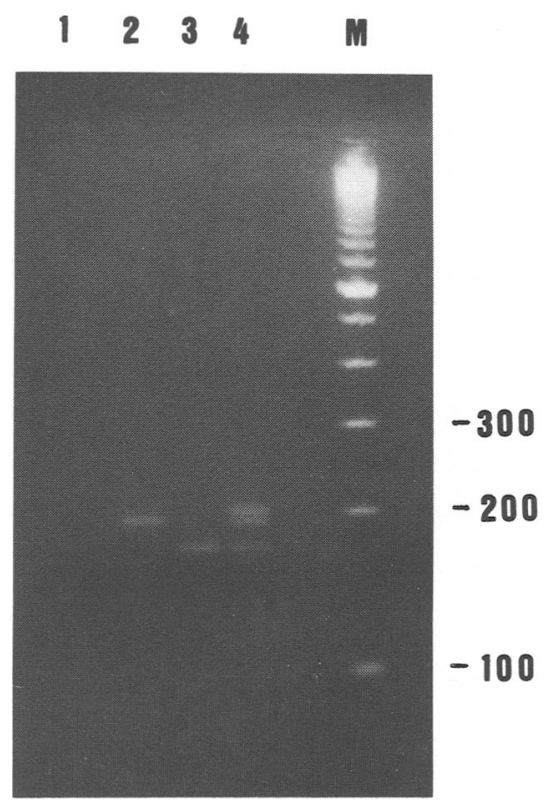

FIGURE 3 Generation of the 220-bp band is independent of DNA synthesis. The 172- and 194-bp PCR products that had been purified by phenol/chloroform extraction and ethanol precipitation to remove Taq polymerase were subjected to mock PCRs, in which all the reagents except Taq DNA polymerase were included, either separately (lanes 2,3, respectively) or together (lane 4 ). Lane 1 is a reagent control containing no DNA, and the 100-bp marker is shown in lane $M$.

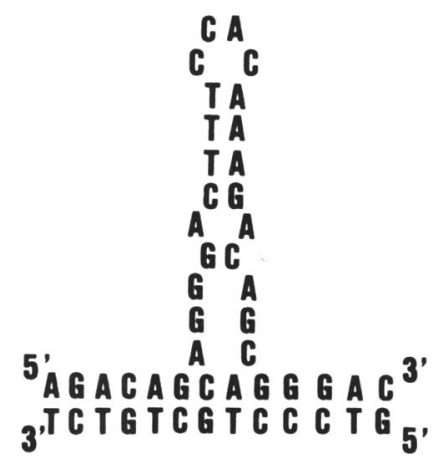

FIGURE 4 A potential stem-loop structure within the duplication that may stabilize heteroduplex formation. The sequence shown corresponds to bases $9366-9400$ of the $\mathrm{SIV}_{\mathrm{pb} \text { i1 }}$ strain containing the 22-bp insertion. The complementary strand shown lacks this sequence.

between the two other products) to anomalous migration through agarose, presumably because of the unusual secondary structure around the region of duplication. During these studies the apparent size of this band was dependent on the rate at which the electrophoresis was performed; at very slow rates it was difficult to resolve from the 194-bp band. In addition, we suspect that heteroduplex formation may have been stabilized, at least in part, by the formation of a stem-loop structure within the duplicated region as illustrated in Figure 4. This structure may explain the relative ease and, hence, relatively high yield, of heteroduplex formation in these studies. Two alternative heteroduplexes can be formed, depending on which of the two strands contains the duplication, and it was determined that the 220-bp band could be resolved into a doublet upon electrophoresis under nondenaturing conditions for extended periods (data not shown).

We are aware that heteroduplex formation during PCR has been described previously by several investigators. For instance, there has recently been a report of the intentional use of these structures to compare amplification of distinct "alleles" of a fragment near the HOX2B locus of closely related species. ${ }^{(13)}$ However, these investigators purposely analyzed their PCR products under denaturing conditions to observe the few base differences present. Unexpected heteroduplex formation has also been observed during analysis of alternative splicing patterns of transcripts of frog neural cell adhesion molecules. ${ }^{(14)}$ In this case, the artifactual bands were minor products of the total PCR, and the most prominent artifact migrated with an apparent size three times that of the true products. In this paper the artifactual band was generated in relatively large amounts, and it migrated with an apparent size not unexpected for a variant containing a second duplication within the LTR target region. Clearly, without further analysis erroneous conclusions regarding mutation at this site could readily be made. This observation brings a cautionary note to the use of PCR in studies in which regulatory regions are targeted. Because regulatory motifs frequently contain palindromic or other sequences that have the potential to form complex secondary structures, which may be integral to the functioning of these sequences, heteroduplex production may be facilitated in these regions. We believe that this was a factor contributing to the high yield of heteroduplex made in these studies. Thus, we would stress the importance of further characterization of unexpected PCR products before making conclusions based solely on their apparent size, particularly when the PCR target region contains variable copy numbers of repeated sequences. The extent to which heteroduplex formation is stabilized at the elevated temperatures used in PCR will clearly depend on the relative size of the PCR target region and the variable duplicated sequence contained within it. Thus, the extent of this problem will need to be assessed in each individual case.

\section{ACKNOWLEDGMENTS}

This work was supported by a contract from the Canadian Red Cross Society. We thank I. Prud'homme and A.M.P. Bouillant for performing the cell culture. Animals were handled by the staff of the primate colony of Health Canada, Tunney's Pasture, Ottawa, Canada.

\section{REFERENCES}

1. Cichutek, K., H. Merget, S. Norley, R. Linde, W. Kreuz, M. Gahr, and R. Kurth. 1992. Development of a quasispecies of human immunodeficiency virus type 1 in vivo. Proc. Natl. Acad. Sci. 89: 7365-7369.

2. Vartanian, J.-P., A. Meyerhans, M. Henry, and S. Wain-Hobson. 1992. High-resolu- 
tion structure of an HIV-1 quasispecies: Identification of novel coding sequences. AIDS 6: 1095-1098.

3. Cheng-Mayer, C., T. Shioda, and J.A. Levy. 1991. Host range, replicative, and cytopathic properties of human immunodeficiency virus type 1 are determined by very few amino acid changes in tat and gp120. J. Virol. 65: 6931-6941.

4. Kuiken, C.L., J.-J. de Jong, E. Baan, W. Keulen, M. Tersmette, and J. Goudsmit. 1992. Evolution of the V3 envelope domain in proviral sequences and isolates of human immunodeficiency virus type 1 during transition of the viral biological phenotype. J. Virol. 66: 4622-4627.

5. Hirsch, V., P. Johnson, and P.M. Zack. 1990. SIV-infected macaques harbour multiple proviral genotypes: Selection of a predominant genotype in tissue culture. Vaccines 90: 379-382.

6. Baier, M., M. Dittmar, K. Cichutek, and R. Kurth. 1991. Development in vivo of genetic variability of simian immunodeficiency virus. Proc. Natl. Acad. Sci. 88: 8126-8130.

7. Almond, N., A. Jenkins, A. Slade, A. Heath, M. Cranage, and P. Kitchin. 1992. Population sequence analysis of a Simian immunodeficiency virus $\left({ }^{32} \mathrm{H}\right.$ reisolate of $\mathrm{SIV}_{\text {mac2s1 }}$ ): A virus stock used for international vaccine studies. AIDS Res. Hum. Retroviruses 8 : 77-88.

8. Dewhurst, S., J. Embertson, D. Anderson, J. Mullins, and P. Fultz. 1990. Sequence analysis and acute pathogenicity of molecularly cloned SIV $_{\text {SMM-PBJ14. Nature }}$ 345: 636-640.

9. Lewis, M.G., P.M. Zack, W.R. Elkins, and P.B. Jahrling. 1992. Infection of rhesus and cynomolgus macaques with a rapidly fatal SIV (SIVsmm/pbj) isolate from sooty mangabeys. AIDS Res. Hum. Retroviruses 8: 1631-1639.

10. Novembre, F., V. Hirsch, H. McClure, and P. Johnson. 1991. Molecular diversity of $\mathrm{SIV}_{\mathrm{smm}} / \mathrm{PBj}$ and a cognate variant, SIV $_{\mathrm{smm}} /$ PGg. J. Med. Primatol. 20: 188-192.

11. Novembre, F.J., P.R. Johnson, M.G. Lewis, D.C. Anderson, S. Klumpp, H.M. McClure, and V.M. Hirsch. 1993. Multiple viral determinants contribute to pathogenicity of the acutely lethal simian immunodeficiency virus SIVsmmPBj variant. $J$. Virol. 67: 2466-2474.

12. Bellas, R.E., N. Hopkins, and Y. Li. 1993. The NF- $\mathrm{B}$ binding site is necessary for efficient replication of simian immunodeficiency virus of macaques in primary macrophages but not in T cells in vitro. $)$. Virol. 67: 2908-2913.

13. Ruano, G. and K.K. Kidd. 1992. Modeling of heteroduplex formation during PCR from mixtures of DNA templates. PCR Methods Applic. 2: 112-116.

14. Zorn, A. and P. Krieg. 1991. PCR analysis of alternative splicing pathways: Identifi- cation of artifacts generated by heteroduplex formation. BioTechniques 11: 181183.

Received August 2, 1993; accepted in revised form November 15, 1993. 


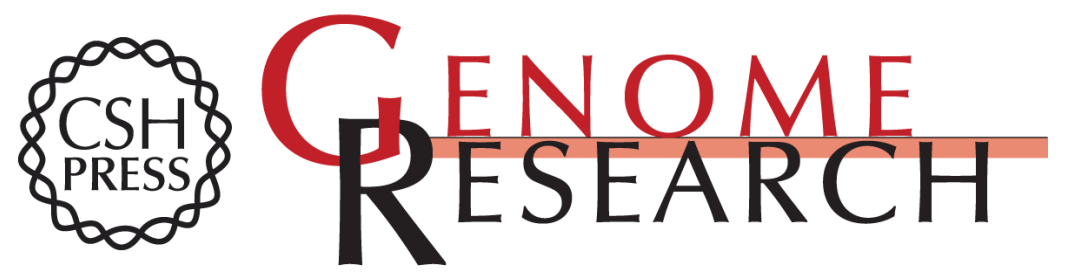

\section{Secondary structure within PCR target sequences may facilitate heteroduplex production.}

E Separovic and S A Nadin-Davis

Genome Res. 1994 3: 248-251

References This article cites 14 articles, 6 of which can be accessed free at: http://genome.cshlp.org/content/3/4/248.full.html\#ref-list-1

\section{License}

Email Alerting

Receive free email alerts when new articles cite this article - sign up in the box at the Service top right corner of the article or click here.

\section{Affordable, Accurate Sequencing.}

To subscribe to Genome Research go to: https://genome.cshlp.org/subscriptions 